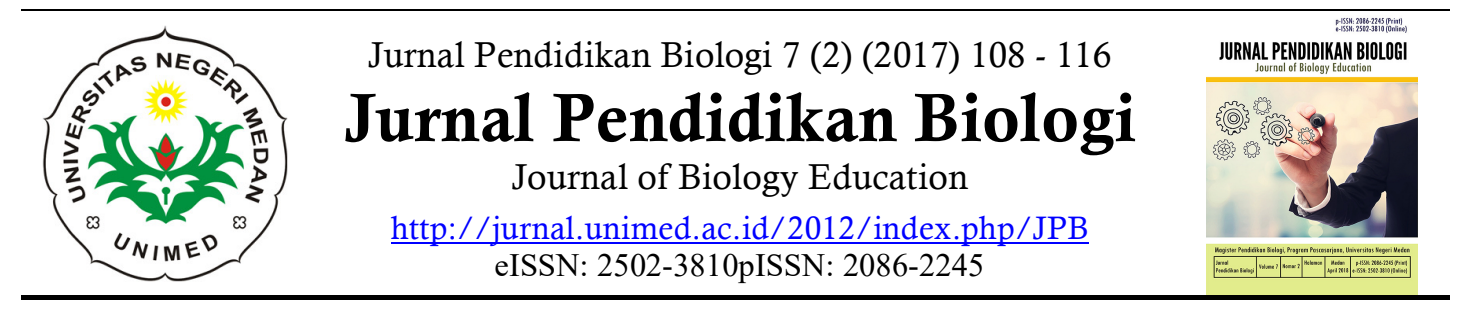

\title{
The Comparison of Student Achievement and Student Activity in Cooperatif Learning With TPS and STAD at TopicofCellin Senior High School
}

\author{
Nora Alisa Pulungan* \\ Institut Pendidikan Tapanuli Selatan \\ *Korespondensi: pulungan.alisa@gmail.com
}

\begin{abstract}
The objective of this research is to know the comparisonof student achievement and student activity in cooperative learning with TPS (Think-Pair-Share) and with STAD (Student Teams-Achievement Division) at topic ofcell in XI class SMA Negeri 5Padangsidimpuan on academic year 2017/2018. The population of this research was the whole students of grade XI SMA Negeri 5Padangsidimpuan in academic year 2017/2018 which consists of 5 classes with the total number of te students are 250 students. The sample of this research was taken by random sampling, where class $\mathrm{XI}_{2}, 40$ students is as the TPS class and class $\mathrm{XI}_{3}, 40$ students, is as the STAD class. The research was conducted by experiment research in which its objective is to know the comparison of applying the two methods.Based on the data analysis. There is difference between the student achievement of TPS class and that of STAD class in which the average score of TPS class is 80,00 . Whereas, the average score of STAD class is 71,30 . The student activity also taking part on increase of student achievement, where the percentage of students achievement at TPS class are $86 \%$, as for at STAD class are $79 \%$.It's mean that the students activity gave a good contribution to increase the student achievement. The difference is proven through hypothesis testing by using t-test and the level of significance $\alpha=0,05$, where $t_{a c c}>t_{\text {table }}(4,57>1,99)$, which means that Ho is rejected and Ha is accepted. Finally it is concluded that there is the difference of student achievement and student activity in cooperative learning with TPS (Think-Pair-Share) and with STAD (Student Teams-Achievement Division) at topic ofcell in XI class SMA Negeri 5 Padangsidimpuan.
\end{abstract}

Keyword: Student Achievement, student activity, cooperative learning,TPS,STAD

\section{PENDAHULUAN}

\footnotetext{
Belajar adalah suatu proses usaha yang dilakukan seseorang untuk memperoleh suatu perubahan tingkah laku yang baru secara keseluruhan, sebagai hasil pengalamannya sendiri dalam interaksi
}

dengan lingkungannya Slameto (2003). Dari proses belajar mengajar akan diperoleh suatu hasil, yang pada umumnya di sebut hasil pengajaran, atau dengan istilah tujuan pembelajaran atau hasil belajar. Tetapi agar memperoleh hasil yang optimal, proses belajar mengajar harus dilakukan dengan 
sadar dan sengaja serta terorganisasi secara baik. Sesuai yang dinyatakan oleh Sardiman (2006) bahwa manusia yang hidup dan berkembang adalah manusia yang selalu berubah dan perubahan itu merupakan hasil belajar.

Di dalam belajar diperlukan aktivitas sebab pada prinsipnya belajar adalah berbuat. Hal yang senada diutarakan oleh Sardiman (2006), bahwa belajar adalah suatu aktivitas mental/psikis, yang berlangsung dalam interaksi aktif dengan lingkungan, yang menghasilkan sejumlah perubahan dalam pengetahuan, pemahaman, keterampilan, dan nilai-sikap. Perubahan itu bersifat konstan dan berbekas. Menurut Sutikno dalam Sardiman (2006), bahwa tidak ada belajar kalau tidak ada aktivitas. Itulah sebabnya aktivitas merupakan prinsip atau asas yang sangat penting di dalam interaksi belajarmengajar. Tetapi pada kenyataan di lapangan, guru seringkali mengabaikan kegiatan aktif positif sehingga kelas selalu didominasi oleh aktivitas negatif yang cenderung membuat siswa bosan dalam pembelajaran biologi.

Pada mata pelajaran Biologi terdapat beberapa materi pokok, diantaranya adalah Sel. Sel pertama kali di temukan oleh Robert Hooke tahun 1665 dari pengamatan penampang melintang sayatan tipis gabus dari batang tumbuhan dibawah mikroskop. Sel merupakan unit struktural dan fungsional terkecil pada makhluk hidup. Pada makhluk hidup multiseluler sel-sel yang serupa berkumpul bersama dan menjalankan satu fungsi yang sama membentuk jaringan.

Strategi Think-Pair-Share (TPS) atau berpikir berpasangan berbagi merupakan jenis pembelajaran kooperatif yang dirancang untuk mempengaruhi pola interaksi siswa. Menurut Lyman et all dalam Trianto; 2007, bahwa Think-PairShare merupakan suatu cara yang efektif untuk membuat variasi suasana pola diskuasi kelas. Dengan asumsi bahwa semua resitasi atau diskusi membutuhkan pengaturan untuk mengendalikan kelas secara keseluruhan, dan prosedur yang digunakan dalam Think-Pair-Share dapat memberi siswa lebih banyak waktu berpikir, untuk merespons dan saling membantu.

Adapun langkah-langkah dalam pembelajaran kooperatif pada tipe Think Pair-Share yaitu: a) Berpikir (Thinking) yaitu Guru mengajukan suatu pertanyaan atau masalah yang dikaitkan dengan pelajaran, dan meminta siswa menggunakan waktu beberapa menit untuk berpikir sendiri jawaban atau masalah. Siswa membutuhkan penjelasan bahwa berbicara atau mengerjakan bukan bagian berpikir, $b$ ) Berpasangan (Pairing) yaitu Selanjutnya guru meminta siswa untuk berpasangan dan mendiskusikan apa yang telah mereka peroleh. Interaksi selama waktu yang disediakan dapat menyatukan jawaban jika suatu pertanyaan yang di ajukan atau menyatukan gagasan apabila suatu masalah khusus yang di identifikasi. Secara normal guru memberi waktu tidak lebih dari 4 atau 5 menit untuk berpasangan. c) Berbagi (Sharing) yaitu Pada langkah akhir, guru meminta pasangan-pasangan untuk berbagi dengan keseluruhan kelas yang telah mereka bicarakan. Hal ini efektif untuk berkeliling ruangan dari pasangan ke pasangan dan melanjutkan sampai sekitar sebagian pasangan mendapat kesempatan untuk melaporkan (Trianto, 2007).

Pembelajaran kooperatif tipe STAD merupakan salah satu tipe dari model pembelajaran kooperatif dengan menggunakan kelompok-kelompok kecil dengan jumlah anggota tiap kelompok 4-5 orang secara heterogen. Diawali dengan penyampaian tujuan pembelajaran, penyampaian materi, kegiatan kelompok, kuis, dan penghargaan kelompok. 


$\begin{array}{rrcr}\text { Slavin } & \text { dalam } & \text { (Trianto, } & \text { 2007) } \\ \text { menyatakan } & \text { bahwa } & \text { STAD } & \text { siswa } \\ \text { ditempatkan } & \text { pada } & \text { tim } & \text { belajar }\end{array}$
beranggotakan 4-5 orang yang merupakan campuran menurut tingkat prestasi, jenis kelamin, dan suku. Guru menyajikan pelajaran dan kemudian siswa bekerja dalam tim mereka memastikan bahwa seluruh anggota tim telah menguasai pelajaran tersebut. Kemudian, seluruh siswa diberikan tes tentang materi tersebut, pada saat tes ini mereka tidak diperbolehkan saling membantu.

Menurut (Ibrahim, 2009) kelebihan dari metode kooperatif tipe STAD adalah : (a) pembelajaran tidak membosankan karena setiap siswa aktif untuk memaparkan konsep-konsep menurut pemikirannya, (b) pengetahuan yang diperoleh melalui diskusi antar anggota yang saling berperan sebagai tutor untuk anggota kelompoknya akan berusaha menjelaskan konsep sesuai dengan pengertiannya masing-masing sehingga akan lebih mudah dipahami karena bahasa yang digunakan lebih sederhana dan pengetahuan yang diperoleh dengan cara ini akan bertahan lama, (c) memberikan peluang kepada siswa yang berbeda latar belakang untuk bekerja dalam tugas sehingga timbul penerimaan yang luas terhadap anggota yang berbeda kemampuan, kelas sosial, dan budayanya, (d) meningkatkan kemampuan untuk kooperaitf.

\section{METODOLOGI PENELITIAN}

Penelitian ini dilaksanakan di SMA Negeri 5 Padangsidimpuan Tahun Pembelajaran 2017/2018. Alasan penulis memilih lokasi penelitian ini karena ditemukan masalah ketidaktuntasan hasil belajar Biologi di SMA Negeri 5 Padangsidimpuan sehingga tidak mencapai Kriteria Ketuntasan Minimal (KKM) yang ditetapkan dan penulis ingin memberikan inovasi baru dalam dunia pendidikan khususnya dalam proses pembelajaran materi pokok sistem Sel. Pelaksanaan penelitian ini dilaksanakan selama \pm 3 bulan terhitung mulai Februari - April 2018.

Dalam penelitian ini populasi yang digunakan adalah seluruh siswa kelas XI SMA Negeri 5Padangsidimpuan yang berjumlah 5 kelas. Ada dua kelas yang akan dijadikan sampel penelitian yaitu kelas sampel $\mathrm{XI}_{3}$ yang mendapatkan model pembelajaran kooperatif tipe STAD, kelas sampel $\mathrm{XI}_{2}$ yang mendapatkan model pembelajaran kooperatif tipe TPS.

Sampel adalah bagian dari populasi yang diteliti. Pengambilan sampel menggunakan teknik random sampling. Sampel dalam penelitian ini dengan mengambil dua kelas dari lima kelas yang ada masing-masing berjumlah 40 orang sehingga dengan jumlah siswa sampel adalah 80 orang siswa.

Variabel Penelitiany yang digunakan adalah Variabel Bebas dan Variabel Terikat. Variabel Bebas Variabel bebas dari penelitian ini adalah pengajaran yang diberikan dengan menggunakan model pembelajaran kooperatif dengan tipe TPS (Think-Pair-Share) dan model pembelajaran kooperatif tipe STAD (Student TeamsAchievement Division). Variabel Terikat Variabel terikat pada penelitian ini adalah keterlibatan siswa pada masing-masing tipe model pembelajaran serta hasil belajar yang diperoleh siswa pada materi pokok Sel.Jenis Dan Sumber Data yang di gunakan peneliti dalam penelitian ini jenis data yang dibutuhkan adalah data kuantitatif. Disebut data kuantitatif karena data tersebut berupa nilai atau angka-angka dari hasil belajar siswa.

Sumber data dari penelitian ini diperoleh dari hasil belajar siswa kelas XI semester ganjil SMA Negeri 5 Padangsidimpuan Batu Tahun 
Pembelajaran 2017/2018. Skor yang digunakan sebagai peneliti adalah skor dan item yang valid dan reliable. Tes ini digunakan untuk mengetahui hasil belajar siswa dalam kegiatan belajar mengajar pada materi pokok Sel.

Penelitian ini melibatkan perlakuan yang berbeda yaitu antara kelompok kelas yang diberi pengajaran dengan menggunakan model pembelajaran kooperatif tipe TPS (Think-Pair-Share) dan tipe STAD ( Student Teams-Achievement Division). Untuk lebih jelasnya dapat dilihat tabel model desain pre-test dan post-test.

\section{HASIL PENELITIAN}

Berdasarkan penelitian pada bagian ini akan diuraikan secara terperinci mengenai hasil dari penelitian tentang perbandingan hasil belajar dan aktivitas siswa dalam model pembelajaran kooperatif tipe TPS (Think-Pair-Share) dengan tipe STAD (Student Teams-Achievement Division) pada materi pokok sel di kelas XI SMA Negeri 5Padangsidimpuan Tahun Pembelajaran 2017/2018. Sebelum melaksanakan penelitian, terlebih dahulu peneliti melakukan ujicoba instrumen untuk mengetahui tingkat validitas dan reliabilitas instrumen. Dari hasil ujicoba instrumen yang terdiri dari 40 butir pertanyaan diketahui 25 soal dinyatakan valid, dan 15 soal lainnya dinyatakan tidak valid. Berdasarkan hasil tersebut, maka jumlah butir soal yang digunakan untuk mendapatkan data penelitian sebanyak 25 butir yang telah dinyatakan valid. Sedangkan butir soal yang dinyatakan tidak valid tidak diikutkan dalam penelitian.

Hasil perhitungan reliabilitas diperoleh nilai $r_{\text {hit }}=0,825$ yang berarti bahwa tingkat reliabilitas instrumen termasuk kategori sangat tinggi. Dari perhitungan tingkat kesukaran soal diketahui 10 soal tergolong kategori mudah, 20 soal tergolong kategori sedang dan 10 soal tergolong kategori sukar. Untuk daya beda soal diketahui 21 soal tergolong kategori baik, 12 soal tergolong kategori cukup dan 7 soal tergolong kategori jelek. Dengan diketahuinya nilai validitas reliabilitas, tingkat kesukaran soal dan daya beda soal tersebut, maka instrumen dinyatakan layak untuk digunakan dalam mendapatkan data penelitian.

Data yang diperoleh dalam penelitian ini terdiri atas dua jenis, pertama adalah data pretes yang digunakan untuk melihat perbandingan pengetahuan awal siswa Kedua adalah data postes atau data hasil belajar siswa setelah diberikan perlakuan dengan menggunakan model pembelajaran yang berbeda.

\section{Deskripsi Data Hasil Pretes Pada Kelas TPS dan Kelas STAD}

Sebelum melaksanakan penelitian dengan pengajaran menggunakan model pembelajaran TPS dan STAD, peneliti terlebih dahulu memberikan pretes pada kedua kelas tersebut untuk mengetahui pengetahuan kedua kelompok siswa pada materi Pokok Sel. Dari hasil pretes tersebut diperoleh nilai rata-rata siswa pada kelas dengan menggunakan model pembelajaran kooperatif tipe TPS sebesar 39,50 dengan simpangan baku (SD) sebesar 8,55 dan varians sebesar 73,18 . Sedangkan untuk kelas dengan menggunakan model pembelajaran kooperatif tipe STAD diperoleh nilai rata-rata siswa sebesar 41,20 dengan simpangan baku (SD) sebesar 8,31 dan varians sebesar 69,09 . Perbedaan nilai pretes pada kedua kelompok penelitian tersebut dapat dilihat pada Tabel 1 di bawah ini. 
Tabel 1.Perbedaan Nilai Pretes Siswa Pada Kelas TPS dan STAD

\begin{tabular}{|c|c|c|c|c|c|c|c|}
\hline \multicolumn{4}{|c|}{ Kelas TPS } & \multicolumn{4}{|c|}{ Kelas STAD } \\
\hline Nilai & $\mathbf{f}$ & & SD & Nilai & $\mathrm{f}$ & & SD \\
\hline 24 & 3 & & & 24 & 0 & & \\
\hline 28 & 3 & & & 28 & 4 & & \\
\hline 32 & 4 & & & 32 & 5 & & \\
\hline 36 & 7 & & & 36 & 6 & & \\
\hline 40 & 8 & 39,50 & 8,55 & 40 & 7 & 41,20 & 8,31 \\
\hline 44 & 6 & & & 44 & 6 & & \\
\hline 48 & 4 & & & 48 & 5 & & \\
\hline 52 & 3 & & & 52 & 4 & & \\
\hline 56 & 2 & & & 56 & 3 & & \\
\hline Jumlah & 40 & - & - & Jumlah & 40 & - & - \\
\hline
\end{tabular}

Untuk lebih jelasnya berikut ini disajikan gambar perbedaan nilai pretes siswa pada kelas TPS dan kelas STAD.

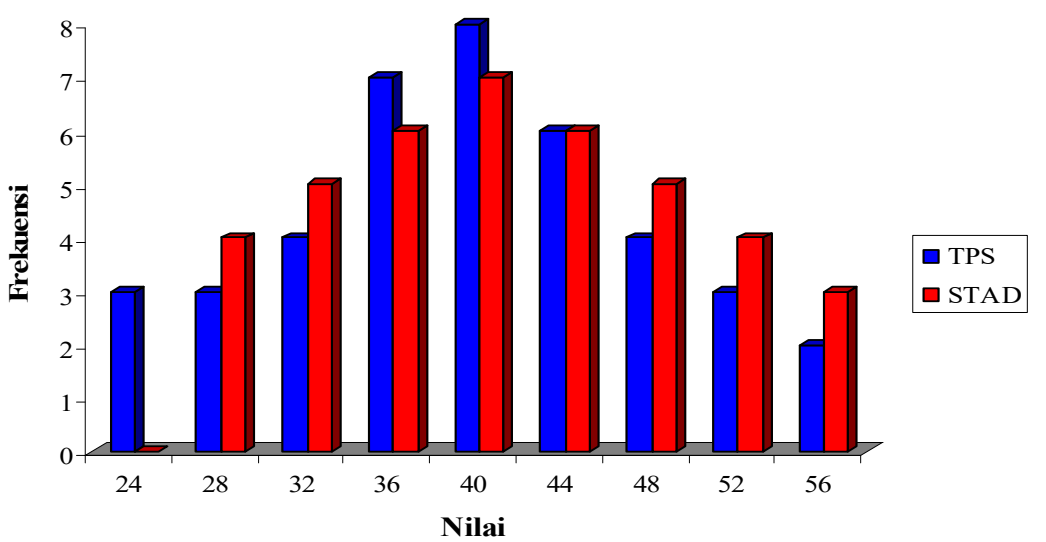

Gambar 1. Diagram Perbedaan Nilai Pretes Siswa Pada Kelas TPS dan STAD

Deskripsi Data Postes Kelas TPS dan Kelas STAD

Nilai postes pada kedua kelompok penelitian diperoleh dari nilai hasil belajar siswa setelah diberikan model pembelajaran yang berbeda. Dari hasil postes untuk kelas TPS diperoleh nilai rata-rata siswa sebesar 80,00 dengan standar deviasi sebesar 9,46 dan varians sebesar 89,44 . Sedangkan untuk kelas STAD diperoleh nilai rata-rata siswa sebesar 71,30 dengan standar deviasi sebesar 7,46 dan varians sebesar 55,70. Perbedaan nilai postes pada kedua kelas penelitian tersebut dapat dilihat pada Tabel 2 di bawah ini.

Tabel 2. Perbedaan Nilai Postes pada Kelas TPS dan STAD

\begin{tabular}{|c|c|c|c|c|c|c|c|}
\hline \multicolumn{4}{|c|}{ Kelas TPS } & \multicolumn{4}{|c|}{ Kelas STAD } \\
\hline Nilai & $\mathbf{f}$ & & SD & Nilai & $\mathbf{f}$ & & SD \\
\hline 64 & 3 & & & 60 & 5 & & \\
\hline 68 & 4 & & & 64 & 6 & & \\
\hline 72 & 4 & 80,00 & 9,46 & 68 & 7 & 71,30 & 7,46 \\
\hline 76 & 6 & & & 72 & 8 & & \\
\hline 80 & 7 & & & 76 & 5 & & \\
\hline
\end{tabular}


Pulungan / Jurnal Pendidikan Biologi 7 (2) (2018) 108 - 116

\begin{tabular}{|c|c|c|c|c|c|}
\hline \multicolumn{3}{|c|}{ Kelas TPS } & \multicolumn{3}{|c|}{ Kelas STAD } \\
\hline Nilai & f & SD & Nilai & f & SD \\
\hline 84 & 5 & & 80 & 5 & \\
\hline 88 & 4 & & 84 & 4 & \\
\hline 92 & 3 & & 88 & 0 & \\
\hline 96 & 4 & & 92 & 0 & \\
\hline Jumlah & 40 & - & Jumlah & 40 & - \\
\hline
\end{tabular}

Untuk lebih jelasnya, di bawah ini disajikan grafik perbedaan nilai postes pada kedua kelas penelitian.

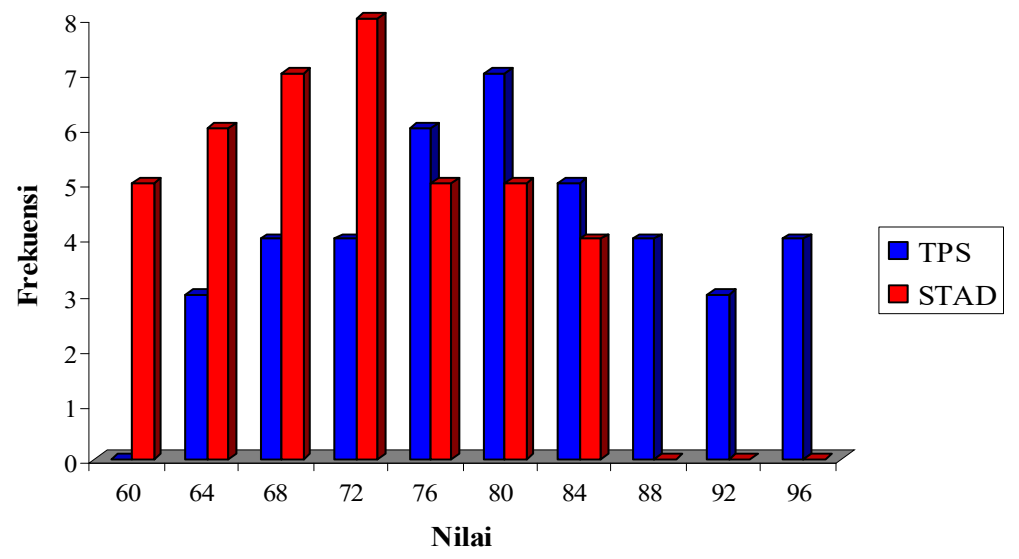

Gambar 2. Diagram Perbedaan Nilai Postes Kelas TPS dan Kelas STAD

Aktivitas Belajar Siswa dalam penting dalam menunjang hasil belajar Pembelajaran Biologi Pada kelas TPS Dan siswa. Ini berarti antara hasil belajar dengan Kelas STAD

Jika dilihat dari aktivitas belajar siswa terdapat perbedaan antara kelas TPS dan kelas STAD, dimana pada kelas TPS ratarata persentase aktivitas belajar siswa adalah $86 \%$ dan pada kelas STAD rata-rata persentase aktivitas belajar siswa adalah 79\%. Jika dihubungkan dengan nilai hasil belajar, pada kelas TPS nilai rata-ratanya adalah 80,00 dan pada kelas STAD nilai rata-ratanya adalah 71,30 . Keterlibatan atau aktivitas siswa dalam kegiatan belajar aktivitas belajar sudah sejalan dengan kata lain aktivitas belajar siswa memberi kontribusi yang baik untuk meningkatkan hasil belajar siswa.Ini berarti bahwa penggunaan model pembelajaran kooperatif tipe TPS lebih efektif digunakan untuk mengajarkan materi pokok Sel dibandingkan dengan model pembelajaran kooperatif tipe STAD. Untuk lebih jelasnya, dibawah ini disajikan grafik perbedaan ratarata persentase aktivitas belajar siswa pada kedua kelas penelitian. 


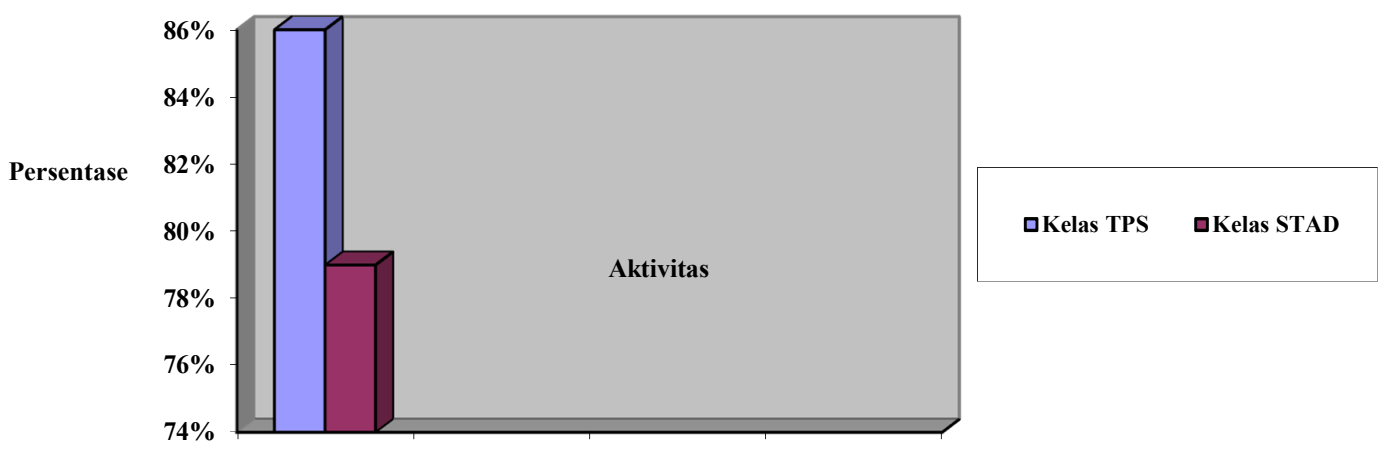

Gambar 3. Diagram perbandingan Aktivitas Siswa Pada Kelas TPS Dan Kelas STAD

Uji persyaratan data meliputi uji normalitas dan uji homogenitas data pretes dan data postes pada kelas TPS dan kelas STAD.

\section{Uji Normalitas}

Uji normalitas dilakukan dengan menggunakan uji liliefors pada taraf signifikan $\alpha=0,05$. Hasil pengujian normalitas data hasil belajar siswa kelas TPS dan kelas STAD dapat dilihat pada tabel berikut ini.

Tabel 3. Hasil Pengujian Normalitas Data Penelitian

\begin{tabular}{ccccc}
\hline \multicolumn{5}{c}{ Pretes } \\
\hline No & Kelas & $\mathbf{L}_{\text {hit }}$ & $\mathbf{L}_{\text {tab }}(\boldsymbol{\alpha}=\mathbf{0 , 0 5})$ & Kesimpulan \\
\hline 1 & TPS & 0.1011 & 0.1401 & Normal \\
2 & STAD & 0.1107 & 0.1401 & Normal \\
\hline & & & Postes & Kesimpulan \\
\hline No & Kelas & $\mathbf{L}_{\text {hit }}$ & $\mathbf{L}_{\text {tab }}(\boldsymbol{\alpha}=\mathbf{0 , 0 5})$ & Normal \\
\hline 1 & TPS & 0.1000 & 0.1401 & Normal \\
2 & STAD & 0.1200 & 0.1401 & \\
\hline
\end{tabular}

\section{Uji Homogenitas}

Uji homogenitas dilakukan dengan membandingkan nilai varians hasil pretes dan hasil postes dari kedua kelompok penelitian. Ringkasan hasil pengujian homogenitas data dapat dilihat pada Tabel 4 di bawah ini.

Tabel 4. Hasil Pengujian Homogenitas Data Penelitian

\begin{tabular}{cccccc}
\hline \multicolumn{5}{c}{ Pretes } \\
\hline No & Kelas & Varians & $\mathbf{F}_{\text {hit }}$ & $\mathbf{F}_{\text {tab }}(\boldsymbol{\alpha}=\mathbf{0 , 0 5})$ & Kesimpulan \\
\hline 1 & TPS & 73,18 & \multirow{2}{*}{1.06} & 1.71 & Homogen \\
\hline 2 & STAD & 69,09 & & Postes & Kesimpulan \\
\hline \multicolumn{7}{c}{ No } & Kelas & Varians & $\mathbf{F}_{\text {hit }}$ & $\mathbf{F}_{\text {tab }}(\boldsymbol{\alpha}=\mathbf{0 , 0 5})$ & Homogen \\
\hline 1 & TPS & 89,44 & 1.61 & 1.71 &
\end{tabular}

Pengujian hipotesis dilakukan dengan memakai uji beda (uji-t) yang membandingkan harga rata-rata dari nilai hasil belajar kedua kelompok penelitian 
setelah diberikan perlakuan dengan model pembelajaran dengan tipe yang berbeda. Dari hasil perhitungan yang dilakukan, diketahui nilai rata-rata kelompok siswa dengan menggunakan model pembelajaran kooperatif tipe TPS adalah sebesar 80,00 sedangkan nilai rata-rata kelompok siswa dengan menggunakan model pembelajaran kooperatif tipe STAD sebesar 71,30. Varians gabungan dari kedua kelompok penelitian sebesar 8,52. Dengan menggunakan nilai rata-rata hasil belajar dan varians gabungan dari kedua kelompok penelitian, maka diketahui besar $t_{h i t}=4,57$. Jika nilai $t_{\text {hit }}$ dibandingkan dengan nilai $t_{\text {tab }}$ dengan $\mathrm{dk}(78)=1,99$, maka diperoleh hasil bahwa $\mathrm{t}_{\text {hit }}<\mathrm{t}_{\text {tab }}(4,57>1,99)$. Jadi dapat disimpulkan bahwa dalam penelitian ini $\mathrm{H}_{0}$ ditolak sekaligus menerima $\mathrm{H}_{\mathrm{a}}$ yang berarti ada perbedaan pembelajaran kooperatif tipe TPS (Think-Pair-Share) dengan tipe STAD (Student Team Achievement Division) terhadap hasil belajar siswa pada Materi Pokok Sel di Kelas XI SMA Negeri 5Padangsidimpuan Tahun Pembelajaran 2017/2018.

\section{PEMBAHASAN}

Dari hasil penelitian yang sudah dilakukan ternyata bahwa nilai rata-rata hasil pretes kedua kelas tersebut relatif tidak berbeda bahkan bisa dikatakan sama. Dimana nilai rata-rata kelompok siswa yang dijadikan kelas TPS sebesar 39,50 dan nilai rata-rata kelas yang dijadikan kelas STAD sebesar 41,20. Berdasarkan nilai rata-rata pretes tersebut terlihat bahwa hasil belajar siswa sebelum diberikan perlakuan dengan model pembelajaran kooperatif tipe yang berbeda masih tergolong sangat rendah. Hal ini dapat dimaklumi, karena kedua kelompok penelitian belum menerima pembelajaran mengenai Materi Pokok Sel. Berdasarkan hasil pretes tersebut didapat gambaran bahwa pengetahuan dari kedua kelompok penelitian mengenai Materi Pokok Sel tergolong sama.

Berdasarkan hasil postes setelah kedua kelompok penelitian diberikan perlakuan dengan menggunakan model pembelajaran dengan tipe yang berbeda diperoleh hasil bahwa rata-rata hasil belajar kelompok siswa yang diajar dengan menggunakan model pembelajaran kooperatif tipe TPS sebesar 80,00 sedangkan nilai rata-rata kelompok siswa yang diajar dengan menggunakan model pembelajaran kooperatif tipe STAD sebesar 71,30. Dari hasil postes ini terlihat bahwa perolehan nilai rata-rata kelompok siswa yang diajar dengan model pembelajaran pembelajaran Kooperatif TPS meningkat sebesar 40,50 satuan dibandingkan dengan nilai pretes atau sebelum diberikan pengajaran, sedangkan nilai rata-rata kelompok siswa yang diajar dengan model pembelajaran kooperatif tipe STAD juga meningkat sebesar 30,10 satuan. Berdasarkan hasil tersebut, terlihat bahwa peningkatan hasil belajar siswa yang diajar dengan model pembelajaran Kooperatif tipe TPS lebih baik jika dibandingkan dengan peningkatan nilai rata-rata kelompok siswa yang diajar dengan menggunakan model pembelajaran kooperatif tipe STAD. Dengan perbandingan besar peningkatan hasil belajar pada kedua kelompok penelitian dapat disimpulkan bahwa penggunaan model pembelajaran kooperatif tipe TPS lebih efektif digunakan untuk mengajarkan Materi Pokok Sel dibandingkan dengan model pembelajaran kooperatif tipe STAD.

\section{KESIMPULAN}

Berdasarkan hasil penelitian dan pembahasan, maka penulis dapat menyimpulkan (1) Hasil belajar siswa pada materi pokok sel dengan menggunakan model pembelajaran kooperatif tipe TPS 
tergolong kategori tinggi dengan nilai ratarata sebesar 80,00; (2) Hasil belajar siswa pada materi pokok sel dengan menggunakan model pembelajaran kooperatif tipe STAD tergolong kategori cukup dengan nilai rata-rata sebesar 71,30; (3) Ada perbedaan pembelajaran kooperatif tipe TPS (Think-Pair-Share) dengan tipe STAD (Student Team Achievement Division) terhadap hasil belajar siswa pada Materi Pokok Sel; (4) Keterlibatan atau aktivitas siswa dalam kegiatan belajar mengajar juga mempunyai peran yang penting dalam menunjang hasil belajar siswa. Pada kelas TPS hasil belajar adalah 80,00 dan persentase aktivitas belajar adalah $86 \%$ sedangkan pada kelas STAD hasil belajar adalah 71,30 dan persentase aktivitas belajar adalah $79 \%$. Ini berarti antara hasil belajar dengan aktivitas belajar sudah sejalan dengan kata lain aktivitas belajar siswa memberi kontribusi yang baik untuk meningkatkan hasil belajar siswa.

\section{DAFTAR PUSTAKA}

Arikunto, S., (2009), Dasar-Dasar Evaluasi Pendidikan, Bumi Aksara, Jakarta.

Aryulina, D., Muslim, C., Manaf, S., Winarni, E.W., (2007), Biologi 2, Penerbit ESIS, Jakarta.

Ibrahim, M., (2009), Pembelajaran Kooperatif, Universitas Negeri Surabaya, Surabaya.

Sardiman, (2010), Interaksi Dan Motivasi Belajar Mengajar, Penerbit Rajawali Pers, Jakarta.

Slameto, (2003), Belajar Dan Faktor-Faktor Yang Mempengaruhinya, PT. Rineka Cipta, Jakarta.

Trianto, (2009), Mendesain Model Pembelajaran Inovatif-Progresif : Konsep, Landasan, Dan Implementasinya Pada Kurikulum Tingkat Satuan Pendidikan (KTSP), Penerbit Kencana, Jakarta. 